\title{
Carbon Dioxide Fluxes on a Soybean Field in Argentina: Influence of Crop Growth Stages
}

\author{
Gabriela Posse $^{1, *}$, Klaus Richter ${ }^{1}$, Jorgelina M. Corin ${ }^{1}$, Nuria A. Lewczuk ${ }^{1}$, Antonio Achkar ${ }^{2}$ and \\ Cesar Rebella ${ }^{1}$ \\ ${ }^{I}$ Instituto de Clima y Agua - Instituto Nacional de Tecnología Agropecuaria (INTA), Hurlingham, Provincia de Buenos \\ Aires, Argentina \\ ${ }^{2}$ Universidad Católica de Santa Fe. Área Informática. Echagüe 7151. Santa Fe. Provincia de Santa Fe, Argentina
}

\begin{abstract}
CO}_{2}$ fluxes were measured in a soybean field in the Province of Buenos Aires, Argentina, with an eddy covariance system consisting of a $\mathrm{CO}_{2} / \mathrm{H}_{2} \mathrm{O}$ infrared gas analyzer and a sonic anemometer. The measurements were carried out between 24th December 2008 and 31st March 2009. The measurements continued to be carried out even after the growing season, in order to capture data on the $\mathrm{CO}_{2}$ fluxes of dying plants and weed plants established after it. Changes in phenology and botanical composition were accompanied with important changes in $\mathrm{CO}_{2}$ flux values and on the relative importance exercised by three meteorological variables selected to describe the environmental condition: solar radiation, air temperature and vapor pressure deficit (VPD). The maximum $\mathrm{CO}_{2}$ fluxes were recorded before noon and reached values up to approximately $1.0 \mathrm{mg} \mathrm{CO} \mathrm{m}^{-2} \mathrm{~s}^{-1}$, having a relation with the global radiation and VPD values. This low value was probably associated with the few rain registered during the spring. When senescence took place, respiration processes became more important and the field acted as a source of $\mathrm{CO}_{2}$. A weak relation was found then with the environmental conditions. Carbon dioxide uptake was reestablished when the soil was covered by weeds but at a much lower rate. The maximum flux value was then around $0.3 \mathrm{mg} \mathrm{m}^{-2} \mathrm{~s}^{-1}$. Carbon dioxide flux was strongly associated with global radiation, which explained $80 \%$ of the variance.
\end{abstract}

Keywords: Phenological stage, eddy covariance, soybean, multiple regressions, carbon sequestration.

\section{INTRODUCTION}

The imbalance between anthropogenic emissions of $\mathrm{CO}_{2}$ and the sequestration of $\mathrm{CO}_{2}$ from the atmosphere by ecosystems has led to an increase in the average concentration of this greenhouse gas (GHG) in the atmosphere [1]. Although industrial activities are mainly responsible for the emission of GHGs, changes in agriculture and land-use also have an important influence on GHG emissions and therefore global warming [2]. In this context, terrestrial ecosystems play a key role in the global carbon cycle because of their function as a potential $\mathrm{CO}_{2}$ sink. An improved understanding of the role played by different ecosystems (forest, grasslands and agroecosystems) at different locations worldwide is essential to obtain global estimations of emissions and the potential of undisturbed ecosystems and sustainable agroecosystems to assimilate $\mathrm{CO}_{2}[3,4]$. Over the past 150 years, the conversion of forests and/or grasslands to agricultural fields has resulted in a $25 \%$ of the increase in the accumulation of $\mathrm{CO}_{2}$ in the atmosphere [5].

There are different methods to investigate the temporal variability of $\mathrm{CO}_{2}$ assimilation and its dependence on the phenological state of the plants or on meteorological parameters [6]. Several of these methods use satellite-based remote

\footnotetext{
*Address correspondence to this author at the Instituto de Clima y Agua. CIRN - CNIA. INTA, Las Cabañas y Los Reseros s/n (1686), Hurlingham, Provincia de Buenos Aires, Argentina; Tel: 54114621 0125/5663/1684; E-mail: gposse@cnia.inta.gov.ar
}

sensing, which allows quantifies the amount of land covered by vegetation and evaluates vegetation-functional aspects [79]. The Normalized Difference Vegetation Index (NDVI), a variable parameter derived from red and near-infrared reflectance, has proven to be a good indicator for crops [10] and natural vegetation [11]. Remote sensing provides data on a global scale, but can be related to $\mathrm{CO}_{2}$ fluxes only indirectly $[12,13]$ via the derivation of vegetation indices. Micrometeorological techniques, however, can be used to measure fluxes of gases, such as $\mathrm{CO}_{2}$ and water vapor, between the ecosystem and the atmosphere directly [14]. These fluxes can be determined by using the method of covariance of turbulent flow (eddy covariance), calculated from measurements of wind speeds over a coordinated system and the gas concentration in the air. The data obtained with eddy covariance provides information about the diurnal, seasonal and long-term changes of the fluxes; they are particularly suitable to monitor the amount of carbon sequestered and emitted during a growth cycle by ecosystems, such as agricultural land, and to determine the carbon balance $[2,15,16]$. Measurements of different crop systems with different farming practices showed that cropland management has a strong impact on the $\mathrm{CO}_{2}$ flux dynamics and on net ecosystem production $[2,3]$.

Argentina is an important country with respect to crop production. Soybean is currently cultivated on approximately 19 million hectares, which represent more than half of the country-wide agricultural land devoted to crop cultivation. 
The frontier of agricultural land has shifted in the recent decades at the expense of grasslands and native forests. Despite the strong impact of this change in land use, the losses of soil organic carbon and the resulting GHG emissions have not yet been comprehensively investigated in Argentina. The lack of precise quantitative data on the emission and sequestration of $\mathrm{CO}_{2}$ of the main agricultural production systems hampers the implementation of improved farming practices that can either reduce emissions or at least mitigate their increase.

The aim of this paper is to describe the effect of environmental conditions on carbon flux, within and between days in a soybean monoculture during an extreme dry summer. Three different phases according to different phenological soybean stages were selected and compared using multiple regression analysis. The relationship between $\mathrm{CO}_{2}$ flux and three meteorological variables: air temperature, vapor pressure deficit and global radiation were also evaluated.

\section{MATERIALS AND METHODS}

\section{Study Site}

Eddy covariance measurements took place on a 360 ha soybean field between December 19th 2008 and March 31st 2009 in Campo de Mayo (34³1'34"S and 58 $39^{\circ} 55^{\prime \prime}$ W), located approximately $30 \mathrm{~km}$ West of the city of Buenos Aires, Argentina. The climate is temperate with a mean air temperature of $24{ }^{\circ} \mathrm{C}$ in the summer and $10^{\circ} \mathrm{C}$ in the winter, with an average annual precipitation of $1147 \mathrm{~mm}$. The soil at this site is classified as a Phaeozem (FAO) and is located $30 \mathrm{~m}$ above sea level. The 2008/2009 growing season experienced unusually dry conditions, which resulted in poor crop productivity. During this dry period, the precipitation was 182.9 $\mathrm{mm}$ between October and December 2008, and $233.6 \mathrm{~mm}$ between January and March 2009. As a means of comparison, the historical mean over 30 years (1961-1990) was 320 $\mathrm{mm}$ between October and December and $375 \mathrm{~mm}$ between January and March. At the end of January, early senescence began and at mid-February the soybean crop perished. Secondary succession by weed plants then took place. The dominant species of the weed plants were Portulaca oleracea $L$ (covering up to $62 \%$ ), followed by Anoda cristata $L$. Schltdl (covering 20\%, estimated through point interception method, data no shown).

The field has been devoted to no-till soybean monoculture cultivation since 1988, and is managed by direct sowing. The sowing usually takes place in October and harvest in March. After harvest the field is abandoned until the next growing season, and secondary succession by weeds occurs after the harvest. In 2008, sowing took place on October $2^{\text {nd }}$. The distance between crop rows was $0.55 \mathrm{~m}$.

\section{Instrumentation and Analysis}

The sensors were installed in the middle of the soybean field approximately $400 \mathrm{~m}$ from the tower. The eddy covariance instruments, consisting of an ultrasonic anemometer (USA-1, METEK, Elmshorn, Germany) and a LI-7500 Open Path $\mathrm{CO}_{2} / \mathrm{H}_{2} \mathrm{O}$ Infrared Gas Analyzer (Li-Cor Inc., Lincoln, Nebraska, USA), were mounted on a $6 \mathrm{~m}$ high metallic scaffold tower at a height of $3.5 \mathrm{~m}$. The data from the anemometer and analyzer were stored with a Panel PC (SYSMEDIA
SRL, Rome, Italy) at a frequency of $20 \mathrm{~Hz}$. The raw data were saved on a computer hard disk in the field. The data were downloaded from the disk twice a month for further data processing, which comprised the calculation of covariances and mean values for periods of 30 minutes. Atmospheric convention was used, with negative flux moving downward from the atmosphere to the ecosystem, and positive flux moving upward. In order to calculate the covariances, the time lag between the anemometer and the analyzer was determined by maximizing the covariance between the datasets of both instruments. The planar fit method was used to correct the datasets for a possible slight inclination of the anemometer [17]. The analysis of the anemometer type (Metek USA-1) required a further correction due to lateral wind and the sonic temperature was converted to air temperature [18]. The $\mathrm{CO}_{2}$ fluxes were calculated by taking into account the fluctuation of air densities, as described by Webb, Pearman and Leuning [19-21]. The flux of $\mathrm{CO}_{2}\left(\mathrm{mg} \mathrm{m}^{-2} \mathrm{~s}^{-1}\right)$ is then given by

$$
F_{\mathrm{CO} 2}=\overline{w^{\prime} \rho_{\mathrm{CO} 2}{ }^{\prime}}+\mu \cdot \overline{\frac{w^{\prime} \rho_{v}}{}{ }^{\prime}} \cdot \overline{\rho_{\mathrm{CO} 2}}+(1+\mu \cdot \sigma) \cdot \overline{\frac{w^{\prime} T^{\prime}}{\bar{T}}} \cdot \overline{\rho_{\mathrm{CO} 2}}
$$

where $\overline{w^{\prime} \rho_{\mathrm{CO} 2}}$ is the covariance of vertical wind speed $w$ $\left(\mathrm{m} \mathrm{s}^{-1}\right)$ and density of $\mathrm{CO}_{2}, \rho_{\mathrm{CO} 2}\left(\mathrm{~kg} \mathrm{~m}^{-3}\right), \overline{w^{\prime} \rho_{v}{ }^{\prime}}$ is the covariance of vertical wind speed and density of water vapor $\rho_{v}$ and $\overline{w^{\prime} \rho_{d}{ }^{\prime}}$ is the covariance of vertical wind speed and density of dry air $\rho_{d} ; \overline{\rho_{\mathrm{CO} 2}}, \overline{\rho_{v}}$ and $\overline{\rho_{d}}$ are the mean densities of $\mathrm{CO}_{2}$, water vapor and dry air $\left(\mathrm{kg} \mathrm{m}^{-3}\right)$, respectively; $\overline{w^{\prime} T}$ is the covariance of vertical wind speed and air temperature; $\bar{T}$ is the mean air temperature $(\mathrm{K}) ; \mu$ is the ratio of molecular mass of dry air and water $(=1.6077)$ and $\sigma$ is the ratio of density of water vapor and density of dry air.

The vapor pressure deficit (VPD, in $\mathrm{Pa}$ ) was calculated using the water vapor density values and air temperatures measured. The stationary conditions of the eddy covariance measurements were tested with the steady state test recommended by Foken and Wichura [22]. The half-hourly data set was partitioned into intervals of 5 minutes and the mean of the covariances of these intervals was compared with the half-hourly covariance. Only fluxes that passed the steady state test were used. The wind came mainly from the North East and South East (35 and 25\% of total frequencies). An average fetch distance of $120 \mathrm{~m}$, which captures $80 \%$ of the $\mathrm{CO}_{2}$ flux, was estimated with the footprint model of Hsieh [23]. Taking into account the distance to the edge of the soybean field, we can conclude that fluxes from outside the field do not significantly contribute to the fluxes measured.

Meteorological data such as daily precipitation (TE525 Campbell Scientific), global radiation (CM3 pyranometer, Kipp \& Zonen), and mean air temperature (108 Temperature Probe, Campbell Scientific, installed at $1.5 \mathrm{~m}$ above ground) were taken every half hour from an automatic station at a distance of $6 \mathrm{~km}$ from the field. Field data such as mean crop height and leaf area index (measured with a portable leaf area meter CI-203, CID Inc) were taken during the soybean peak growth. Since cover dynamics was evaluated with LAI 
measurements, we used values of the normalized difference vegetation index (NDVI) in order to characterize the vegetation growth stages. The NDVI was obtained by reflectance data from band 1 and 2 taken from the MOD09 product. This MODIS product provided composite images every 8 days. The daily diurnal flux values (excluding night data) of the half-hourly data were examined and their relationship with environmental variables (global radiation, vapor pressure deficit and air temperature) tested by simple regression analysis. We then applied a multiple regression analysis to test the improvement of the regression model when all the variables were included in the analysis.

\section{RESULTS}

Crop development, as observed during field observations, was clearly identified on the NDVI progress in time. Three contrasting periods were selected to compare available measurement data at different stages of the status of the soybean field: in the first one (period I), the soybean plants were in their growth peak, although the soil was not completely covered; in the second period (period II), plants were in the senescence stage; during the third period (period III), natural succession took place in the abandoned field and weed species were established. The NDVI course in time reflected these changes (Fig. 1).

\section{Daily Variability}

In period I, when the soybean plants reached the peak of growth (in the growing season studied), the highest $\mathrm{CO}_{2}$ fluxes were around $1.0 \mathrm{mg} \mathrm{m}^{-2} \mathrm{~s}^{-1}$. At night, $\mathrm{CO}_{2}$ was released to the atmosphere by respiration, at a rate of $0.2 \mathrm{mg}$ $\mathrm{m}^{-2} \mathrm{~s}^{-1}$ (Fig. 2). In this period, mean LAI was 1.05, with values between 0.7 and 1.4. Due to the extreme drought in the 2008/2009 summer, the crop did not reach the same maximum height as under normal conditions. The half-hourly diurnal $\mathrm{CO}_{2}$ flux data showed a significant relationship with each of the environmental variables tested: global radiation, vapor pressure deficit and air temperature. Each variable alone explained little of the $\mathrm{CO}_{2}$ flux variance (Table 2). There was a positive relationship with global radiation (the higher the radiation, the higher the $\mathrm{CO}_{2}$ flux) and a negative relationship with VPD and with air temperature (the higher the VPD or temperature, the lower the $\mathrm{CO}_{2}$ flux). In the multiple regression analysis, the best model included global radiation and VPD. Due to the correlation between VPD and temperature in this period, the coefficient of the last variable was not significant $(\mathrm{P}>0.05)$ in the multiple regression analysis. Both significant variables explained $45 \%$ of the total variance $\left(\mathrm{R}^{2}=0.45\right)$, i.e. much more than any of the variables separately. Although the relation between $\mathrm{CO}_{2}$ flux and air temperature is known to be nonlinear, our temperature and global radiation range were limited and the relationship was linear.

In period II, the maximum rate at which $\mathrm{CO}_{2}$ was assimilated were $0.3 \mathrm{mg} \mathrm{m}^{-2} \mathrm{~s}^{-1}$. As the crop was dying, respiration (positive flux values) prevailed over photosynthesis and the $\mathrm{CO}_{2}$ flux values in the course of the day were quite different from those in period I (Fig. 3). The regression analyses showed no significant relation of the $\mathrm{CO}_{2}$ flux with global radiation, but a significant relation with VPD and air temperature. However, the variance, which was explained by

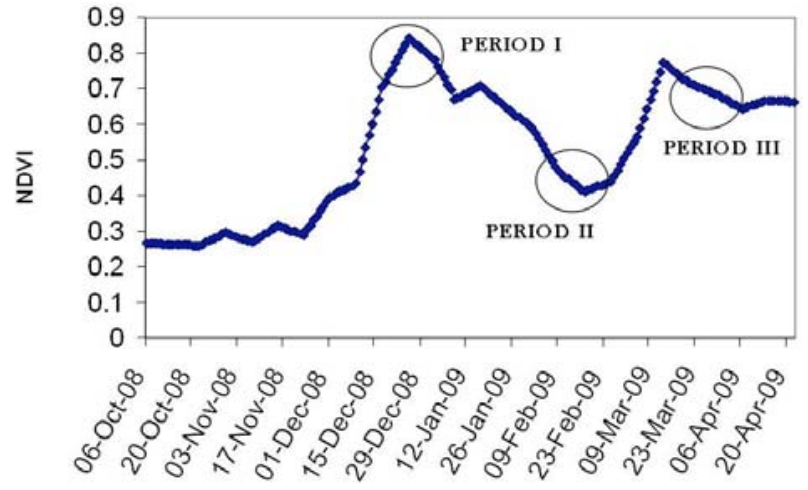

Fig. (1). Normalized Difference Vegetation Index (NDVI) from October 2008 to April 2009 monitored in a soybean monocrop in Buenos Aires province, Argentina. The circles highlight the three periods selected to compare $\mathrm{CO}_{2}$ fluxes.

Table 1. Dates with Rainy Data (in Millimeters) Recorded by Automatic Station at a Distance of $6 \mathrm{~km}$ from the Cultivated Field, from Sowing Day Until the Last Measured Flux Day

\begin{tabular}{|c|c|c|c|}
\hline Date & rain $(\mathrm{mm})$ & Date & rain $(\mathrm{mm})$ \\
\hline 11-Oct-08 & 17.5 & 29-Jan-09 & 0.5 \\
\hline 12-Oct-08 & 2.5 & 30-Jan-09 & 1 \\
\hline 14-Oct-08 & 22 & 02-Feb-09 & 11 \\
\hline 20-Oct-08 & 15 & 05-Feb-09 & 4 \\
\hline 21-Oct-08 & 14 & 10-Feb-09 & 47 \\
\hline 25-Oct-08 & 1.8 & 20-Feb-09 & 8.3 \\
\hline 19-Nov-08 & 0.6 & 21-Feb-09 & 40 \\
\hline 27-Nov-08 & 45 & 22-Feb-09 & 0.5 \\
\hline 29-Nov-08 & 40 & 28-Feb-09 & 4.3 \\
\hline 1-Dec-08 & 1 & 01-Mar-09 & 25 \\
\hline 9-Dec-08 & 12.5 & 03-Mar-09 & 20.5 \\
\hline 21-Dec-08 & 10.5 & 04-Mar-09 & 17.5 \\
\hline 26-Dec-08 & 0.5 & 08-Mar-09 & 1.5 \\
\hline 12-Jan-09 & 0.7 & 10-Mar-09 & 1.5 \\
\hline 17-Jan-09 & 1 & 11-Mar-09 & 8 \\
\hline 24-Jan-09 & 0.4 & 14-Mar-09 & 0.5 \\
\hline 27-Jan-09 & 10 & 23-Mar-09 & 24.8 \\
\hline 28-Jan-09 & 0.6 & 30-Mar-09 & 5 \\
\hline
\end{tabular}

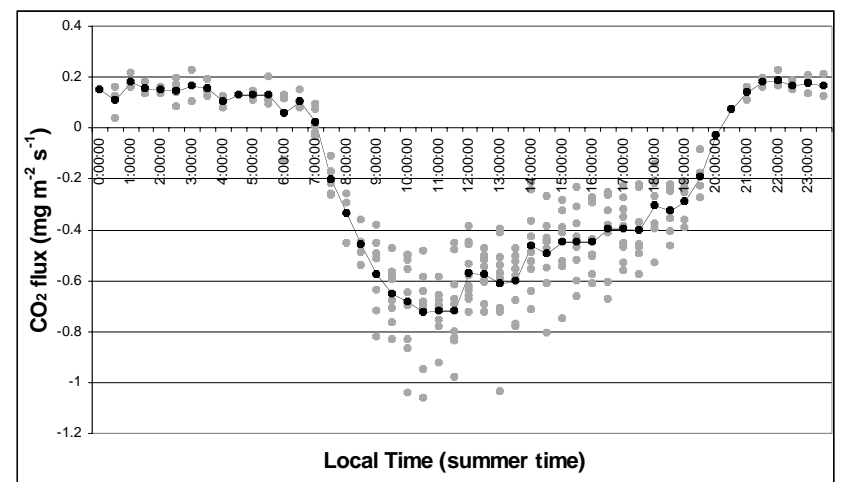

Fig. (2). Carbon dioxide flux over the soybean monocrop on different days in period I (from December 24th 2008 to January 2nd 2009) in Buenos Aires province, Argentina. The line represents halfhourly mean values whereas the dots represent half hourly data.

these two variables, was small: $9.8 \%$ for VPD and $18.8 \%$ for air temperature respect to total variation (Table 3). In the multiple regression analysis, the three variables showed sig- 
Table 2. Values of the Statistical Parameters Obtained by Simple Linear Regression (Line 1, 2 and 3) of the $\mathrm{CO}_{2}$ Flux in Period I and Environmental Variables. The Last Row (Multiple Regression Model) Shows the Parameters Obtained from Best Model of Multiple Regression between the $\mathrm{CO}_{2}$ Flux in Period I and the Three Environmental Variables. Beta is the Slope of the $\mathrm{CO}_{2}$ Flux in $\mathrm{mg} \mathrm{m}^{-2} \mathrm{~s}^{-1}$ Against Global Radiation in $\mathrm{W} \mathrm{m}^{-2}$, VPD in Pa and Air Temperature in ${ }^{\circ} \mathrm{C}$; Intercept is the Value of the $y$-axis Intercept in $\mathrm{mg} \mathrm{m}^{-2} \mathrm{~s}^{-1}, R^{2}$ is the Adjusted Determination Coefficient and $P$ is the Significance Level; Significance is Assumed when $P$ is Lower than 0.05

\begin{tabular}{|c|c|c|c|c|c|}
\hline Simple & Variables & Beta & Intercept & $\mathbf{R}^{2}$ & P \\
\hline \hline 1 & Global radiation & $-2.01 \mathrm{E}-04$ & -0.357 & 0.176 & 0.210 \\
\hline 2 & VPD & $9.45 \mathrm{E}-05$ & -0.704 & 0.145 & 0.000 \\
\hline 3 & Air temperature & $1.499 \mathrm{E}-02$ & -0.883 & 0.455 & 0.000 \\
\hline Multiple & Global radiation & $-2.39 \mathrm{E}-04$ & 0.032 & & \\
\hline & VPD & $1.101 \mathrm{E}-04$ & & \\
\hline
\end{tabular}

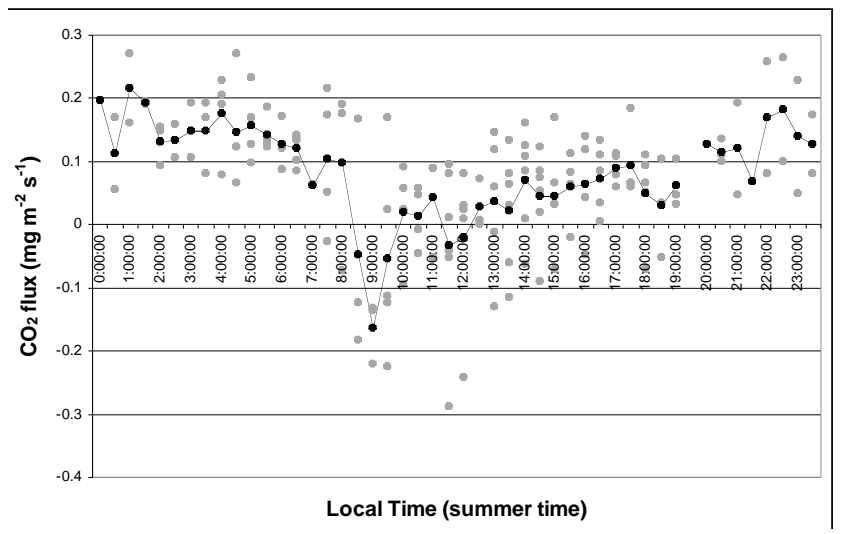

Fig. (3). Carbon dioxide flux over a monocrop soybean field at different days in period II (from 22 to 25 January and 13 to 16 February, 2009) in Buenos Aires province, Argentina The line represents half-hourly mean values whereas the dots represent half hourly data.

nificant coefficients and, together, explained $29 \%$ of the variance (Table 3). It is important to note that in this period the relation between global radiation and air temperature with the $\mathrm{CO}_{2}$ flux was negative and that the relationship with VPD was positive.

In period III, the $\mathrm{CO}_{2}$ fluxes were much lower than in period I, although the soil was almost completely covered with weeds by the secondary succession. The maximum value was around $0.3 \mathrm{mg} \mathrm{m}^{-2} \mathrm{~s}^{-1}$ (Fig. 4). Through respiration, an average of $0.15 \mathrm{mg} \mathrm{m}^{-2} \mathrm{~s}^{-1}$ of $\mathrm{CO}_{2}$ was released to the atmosphere during night. When the single relationships between each variable and the flux value were tested, we found that only global radiation showed a significant relationship and alone explained $77 \%$ of total variance (Table 4). The multiple regression analysis showed that the three variables together explained $81 \%$ of the variance (Table 4 ). The signs of the slope coefficients indicate a positive relationship of $\mathrm{CO}_{2}$ flux with global radiation and temperature, and a negative relationship with vapor pressure deficit.

\section{DISCUSSION}

Our results showed that changes in phenology and botanical composition were accompanied with important changes in $\mathrm{CO}_{2}$ flux values. In period $\mathrm{I}$, when the crop was growing, the maximum of the $\mathrm{CO}_{2}$ fluxes were recorded before noon and reached values up to around $1.0 \mathrm{mg} \mathrm{CO}_{2} \mathrm{~m}^{-2} \mathrm{~s}$ 1 . These flux values are slightly lower than those found by Prueger et al. [24], who report values of up to $1.4 \mathrm{mg} \mathrm{CO}_{2} \mathrm{~m}^{-}$ ${ }^{2} \mathrm{~s}^{-1}$ for a soybean field in the Midwestern USA. This may be due to the intense drought observed during the spring and summer resulting in a depressed growth of the soybean crop. The slow decrease in the afternoon may be related to the lower humidity in the afternoon, leading to a higher vapor pressure deficit, which reduces photosynthesis. The importance of VPD on $\mathrm{CO}_{2}$ fluxes is also stressed by other authors

Table 3. Values of Statistical Parameters Obtained by the Simple (Line 1, 2 and 3) and Multiple Linear Regression Analysis between the $\mathrm{CO}_{2}$ Flux and Environmental Variables in Period II. The Statistical Parameters Beta, Intercept $\mathbf{R}^{2}$ and $P$ are Explained in the Caption of Table 2

\begin{tabular}{|c|c|c|c|c|c|}
\hline Simple & Variables & Beta & Intercept & $\mathbf{R}^{2}$ & P \\
\hline \hline 1 & Global radiation & $4.686 \mathrm{E}-05$ & $2.998 \mathrm{E}-02$ & 0.028 & 0.057 \\
\hline 2 & VPD & $2.689 \mathrm{E}-05$ & $-2.38 \mathrm{E}-02$ & 0.098 & 0.001 \\
\hline 3 & Air temperature & $9.821 \mathrm{E}-03$ & -0.248 & 0.289 & 0.000 \\
\hline Multiple & Global radiation & $5.289 \mathrm{E}-05$ & -0.669 & & \\
\hline & VPD & $-8.71 \mathrm{E}-05$ & & \\
\hline
\end{tabular}




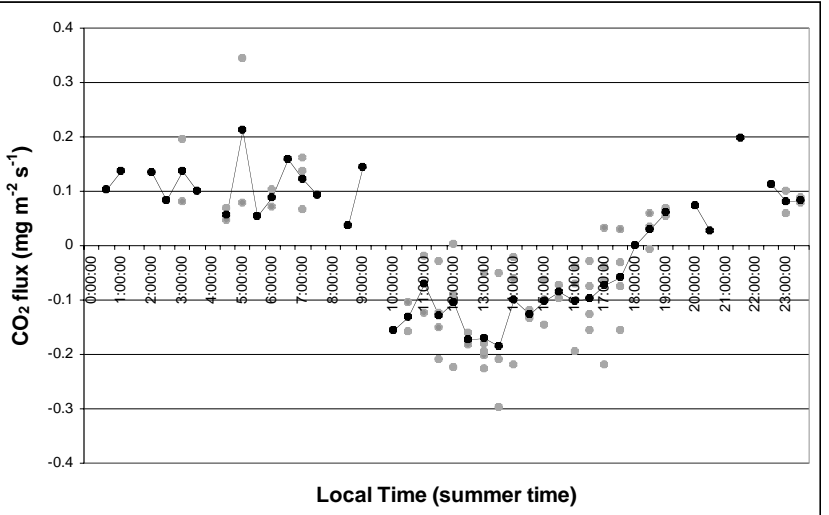

Fig. (4). Carbon dioxide flux over the previous monocrop soybean field, which were succeeded by weeds on different days in period III (from March 23rd to March 31st, 2009) in Buenos Aires province, Argentina. The line represents half-hourly mean values whereas the dots represent half-hourly data.

[e.g. 3, 25], who argue that high VPD leads to higher a stoma resistance and consequently reduced $\mathrm{CO}_{2}$ assimilation. In period I two of the three environment variables (global radiation and vapor pressure deficit) could explain almost half of the variance of all half hourly data in the period (Table 2). Air temperature alone showed a slight relationship with the $\mathrm{CO}_{2}$ flux $\left(\mathrm{R}^{2}=0.145\right)$ but its consideration in the multiple regression did not improve significantly the multiple regression due to its correlation with the VPD values. During this period, soybeans were growing under poor environmental conditions, because they were suffering from water stress. The global radiation explains only $18 \%$ of the variance.

When the senescence process takes place (period II), respiration processes became more important and had a strong influence on the $\mathrm{CO}_{2}$ exchange. Only little variance $(29 \%)$ could then be explained with the meteorological variables. Obviously the photosynthesis is nearly broken down and is replaced by physiological processes related with the dying plants. There is only a small effect of radiation on the $\mathrm{CO}_{2}$ flux data, probably because photosynthesis is not any more the dominating process. The most influential variable in this period was air temperature, which showed a negative relationship with the $\mathrm{CO}_{2}$ flux. This negative dependence can be explained by a greater respiration rate, which increases with rising temperatures.
Carbon dioxide uptake is reestablished when the soil is covered by weeds (period III) but at a lower rate, as was shown by Beziat et al. [3]. Global radiation showed the highest influence on the $\mathrm{CO}_{2}$ flux assimilation, explaining $77 \%$ of the total variance. Although soil water content measurements are not available, it can be assumed due to the rain which occurred in this period (Table 1), that the soil water content increased. These improved environmental conditions favored the growing of weed plants, with the result that $\mathrm{CO}_{2}$ is again assimilated by the biosphere. This explains why in the regression analysis global radiation becomes again an influential variable, which even explained $77 \%$ of the total variance. Contrary to the findings in the previous periods, temperature and VPD had a positive relationship with $\mathrm{CO}_{2}$, however with very low contributions to the total variance.

\section{CONCLUSIONS}

The $\mathrm{CO}_{2}$ fluxes from the soybean monocrop during the extremely hot and dry summer studied showed very different diurnal time course, which depended on the selected periods (peak of soybean growth, death of plants due to the drought, and establishment of weed plants). A maximum of approximately $1.0 \mathrm{mg} \mathrm{CO} \mathrm{m}^{-2} \mathrm{~s}^{-1}$ was measured for the $\mathrm{CO}_{2}$ flux when the soybean plants were growing. As flux data are not available for the whole growing season, the net ecosystem exchange could not be determined for the whole growth cycle. However, the results allowed us to exemplify the changes that took place in the $\mathrm{CO}_{2}$ balance at different growing stages, both during and after soybean growth. Additionally, a further understanding of the processes that influence the assimilation of $\mathrm{CO}_{2}$ allow more precise estimations of the net carbon exchange with models, which take into account meteorological variables considering each growth stage particularities.

\section{ACKNOWLEDGEMENTS}

Financial support was provided by INTA (project AERN 3632). The Catholic Santa Fe University contributed with a very valuable instrument used on the field, through the assistance of Rudy Grether. The Argentine army seeded the study site and provided field support. We especially thank Colonel Passoli and Lieutenant Colonel Martinez. The doctoral studies of Jorgelina Corin support are supported by CONICET. We appreciate the assistance of Piedad Cristiano, Martín Bellomo, Emiliano Melchiori, Ignacio Oesterheld and Ale-

Table 4. Values of Statistical Parameters Obtained by the Simple (Line 1, 2 and 3) and Multiple Linear Regression Analysis between the $\mathrm{CO}_{2}$ Flux and Environmental Variables in Period III. The Statistical Parameters Beta, Intercept $R^{2}$ and $P$ are Explained in the Caption of Table 2

\begin{tabular}{|c|c|c|c|c|c|}
\hline Simple & Variables & Beta & Intercept & $\mathbf{R}^{2}$ & 0.769 \\
\hline \hline 1 & Global radiation & $-2.64 \mathrm{E}-04$ & $3.356 \mathrm{E}-02$ & 0.004 & 0.000 \\
\hline 2 & VPD & $-7.45 \mathrm{E}-06$ & $-6.96 \mathrm{E}-02$ & 0.058 & 0.054 \\
\hline 3 & Air temperature & $-5.46 \mathrm{E}-03$ & -0.248 & 0.206 & 0.000 \\
\hline Multiple & Global radiation & $-2.37 \mathrm{E}-04$ & & \\
\hline
\end{tabular}


jandro Thompson in the field. The support of CIM, Frankfurt, Germany, for one of the authors (K. Richter) is also gratefully acknowledged. Finally, we thank the three reviewers for their valuable comments and suggestions that greatly improved the paper.

\section{REFERENCES}

[1] Keeling CD, Whorf TP. In: Boden TA, Kaiser DP, Sepanski RJ, Stoss FW, Eds. Atmospheric $\mathrm{CO}_{2}$ records from sites in the $\mathrm{SIO}$ air sampling network.Trends'93: a compendium of data on global change. T.A.,ORNL/CDIAC-65. Carbon Dioxide Information Analysis Center, Oak Ridge National Laboratory, Oak Ridge, Tenn., USA 1994; pp. 16-26.

[2] Baker JM, Griffis TJ. Examining strategies to improve the carbon balance of corn/soybean agriculture using eddy covariance and mass balance techniques. Agric Forest Meteorol 2005; 128: 163-77.

[3] Beziat P, Ceschia E, Dedieu G. Carbon balance of a three crop succession over two cropland sites in South West France. Agric Forest Meteorol 2009; 149: 1628-45.

[4] Baldocchi DD, Finnigan JJ, Wilson KW, Paw UKT, Falge E. On measuring net ecosystem carbon exchange in complex terrain over tall vegetation. Boundary Layer Meteorol 2000; 96: 257-91.

[5] Desjardins RL, Sivakumar MVK, de Kimpe C. The contribution of agriculture to the state of climate: workshop summary and recommendations. Agric Forest Meteorol 2007; 142(2-4): 314-24.

[6] Cramer W, Kicklighter DW, Bondeau A, et al. Comparing global models of terrestrial net primary productivity (NPP): overview and key results. Item Corporate Author Participants Potsdam NPP Model Intercomparison 1999; 5(Suppl 1): 1-15.

[7] Running SW, Nemani RR, Heinsch FA, Zhao M, Reeves M, Hashimoto H. A continuous satellite-derived measure of global terrestrial primary production. Bioscience 2004; 54(6): 547-60.

[8] Paruelo JM, Golluscio RA. Range assessment using remote sensing in Northwest Patagonia (Argentina). J Range Manage 1994; 47: 498-502.

[9] Reed BC, Brown JF, Vanderzee D, Loveland TR, Merchant JW, Ohlen DO. Measuring phenological variability from satellite imagery. J Veg Sci 1994; 5: 703-14.

[10] Kumar M, Monteith JL. Remote sensing of crop growth. In: Smith $\mathrm{H}$, Ed. Plants and the daylight spectrum. Academic Press: London 1982; pp. 133-44.

[11] Gamon JA, Field CB, Goulden ML, et al. Relationships between NDVI, canopy structure and photosynthesis in three Californian vegetation types. Ecol Appl 1995; 5: 28-41.
[12] Hill MJ, Held AA, Leuning R, Coops NC, Hughes D, Cleugh HA. MODIS spectral signals at a flux tower site: relationships with high-resolution data and $\mathrm{CO}_{2}$ flux and light use efficiency measurements. Remote Sens Environ 2006; 103: 351-68.

[13] Running SW, Baldocchi DD, Turner D, Gower ST, Bakwin P, Hibbad K. A global terrestrial monitoring network, scaling tower fluxes with ecosystem modeling and EOS satellite data. Remote Sens Environ 1999; 70: 108-27.

[14] Baldocchi DD. Assesing the eddy covariance technique for evaluating carbon dioxide exchange rates of ecosystems: past, present and future. Global Change Biol 2003; 9: 479-92

[15] Hollinger SE, Bernacchi CJ, Meyers TP. Carbon budget of mature no-till ecosystem in North Central Region of the United States. Agric Forest Meteorol 2005; 130: 59-69.

[16] Aubinet M, Moureaux C, Bodson B, et al. Carbon sequestration by a crop over a 4-year sugar beet/winter wheat/seed potato/winter wheat rotation cycle. Agric Forest Meteorol 2009; 149: 407-18.

[17] Wilczak JM, Oncley, SP, Page SA. Sonic anemometer tilt correction algorithms. Boundary Layer Meteorol 2001; 99: 127-50.

[18] Schotanus P, Nieuwstadt FTM, DeBruin HAR. Temperature Measurement with a Sonic Anemometer and its Application to Heat and Moisture Fluxes. Boundary Layer Meteorol 1983; 26: 81-93.

[19] Webb EK, Pearman GI, Leuning R. Correction of flux measurements for density effects due to heat and water vapour transfer. Quart J Roy Meteorol Soc 1980; 106: 85-100.

[20] Leuning R. Measurement of trace gas fluxes in the atmosphere using eddy covariance: WPL corrections revisited. In: Lee X, Massman WJ, Law B, Eds. Handbook of micrometeorology: a guide for surface flux measurement and analysis. Kluwer, Dordrecht 2004; 119-32.

[21] Leuning R. The correct form of the Webb, Pearman and Leuning equation for eddy fluxes of trace gases in steady and non-steady state, horizontally homogeneous flows. Boundary Layer Meteorol 2007; 123: 263-7.

[22] Foken T, Wichura B. Tools for quality assessment of surface-based flux measurements, Agric Forest Meteorol 1996; 78: 83-105.

[23] Hsieh CI, Katul G, Chi T. An approximate analytical model for footprint estimation of scalar fluxes in thermally stratified atmospheric flows. Adv Water Resourc 2000; 23: 765-72.

[24] Prueger JH, Hatfield JL, Parkin TB, Kustas WP, Kaspar TC. Carbon dioxide dynamics during a growing season in midwestern cropping systems. Environ Manage 2004; 33(1): 330-43.

[25] Jing W, Yu Q, Li J, et al. Simulation of diurnal variation of $\mathrm{CO}_{2}$, water and heat fluxes over winter wheat with a model coupled photosynthesis and transpiration. Agric Forest Meteorol 2006; 137: 194-219.

This is an open access article licensed under the terms of the Creative Commons Attribution Non-Commercial License (http://creativecommons.org/licenses/ by-nc/3.0/) which permits unrestricted, non-commercial use, distribution and reproduction in any medium, provided the work is properly cited. 